\title{
TĖVYNĖS GYNIMAS GINKLU - NUODĖMĖ AR DORYBÉ? KATALIKŲ BAŽNYČIOS POŽIŪRIS
}

Teologijos mokslų doktorantas lic. Gabrielius Edvinas Klimenka Vytauto Didžiojo universitetas, Lietuvos šauliu sajunga

Anotacija. Romos Kataliku Bažnyčios tikintieji anksčiau ar véliau kelia klausima - ka derètu daryti tévynę užpuolus agresoriui. Straipsnyje apžvelgiamas Katalikų Bažnyčios mokymas akcentuojant bütent tèvynés gynimo ginklu moraluma. Apžvelgiamas Romos Katalikų Bažnyčios požiūris ị karo ir taikos sampratą. Išryškinami momentai, kuriais atvejais ginkluotas pasipriešinimas neperžengia būtinosios ginties ribu, o kada gynyba yra neteisèta ir nepateisinama, salygos, kuriomis leistina ginkluota savo krašto gynyba, paliečiama biblinè gynybos samprata.

Pagrindiniai žodžiai: Ginkluota gynyba, būtinoji gintis, karas, moraline teologija, Romos Kataliku Bažnyčios požiūris.

\section{IVADAS}

Tiek tikintieji, tiek sekuliarūs visuomenès nariai dažnai ịsitikinę, jog Romos Katalikų Bažnyčios doktrina net ir karo atveju draudžia gynybai naudoti ginklus ir žudyti agresorius. Čia paprastai laikomasi Dekalogo draudimo žudyti. Katalikų Bažnyčia dažniausia laikoma ultrapacifistinių pažiūrų organizacija, o kariuomenejje tarnaujantys kapelionai šiuo atveju kelia kognityvini disonansą, o neretai ir pasipiktinimą dèl to, kad katalikų dvasininkai laimina karius ir jų ginklus. Šios idejjos visuomenejje, bent jau toje jos dalyje, kuri save laiko krikščionimis, atgijo po filmo „Pjūklo ketera“ („Hacksaw Ridge“, 2016), kuriame rodoma Antrojo pasaulinio karo dalyvio Desmondo Doso gyvenimo istorija, peržiūros. Jis - ypač religingas jaunuolis, kuriam ịsitikinimai draudžia žmogui atimti gyvybę. Tačiau, jo manymu, tai netrukdo stoti $\mathfrak{i}$ kariuomenę, bet tarnaudamas 
joje išsikovoja teisę neimti ginklo ị rankas ${ }^{1}$. Nors filmo herojus priklausė adventistams, tūlam tikinčiajam, taip pat ir katalikui, toks požiūris atrodo priimtinas. Tad šiame straipsnyje bandysime išsiaiškinti, koks iš tiesų yra Romos Katalikų Bažnyčios požiūris ị tèvynès gynimą ginklu. Viliamès, kad tai padès abejojantiems dèl karo atveju galimo ginkluoto pasipriešinimo moralumo susivokti, kokia iš tiesų yra katalikiškoji gynimosi ginklu samprata.

Svarstydami šią temą - tèvynès gynimo ginklu ${ }^{2}$ klausimą - nuodemè tai ar dorybè, atliksime Romos Katalikų Bažnyčios dokumentų, kuriuose kalbama apie gynybą karo atveju, analizę.

\section{KARAS IR TAIKA: ROMOS KATALIKŲ BAŽNYČIOS MAGISTERIUMO VERTINIMAS}

Kaip pažymėjo religijotyrininkas Gintaras Beresnevičius, „mes, europiečiai, turime ilgą <...> religinių karų patirtị “3, todèl, savaime suprantama, formuojant požiūrị ị karo ir gynybos jo metu moralumą, Romos Katalikų Bažnyčia (toliau - RKB) turèjo galimybę ne vieną šimtmetį ne tik teoriškai svarstyti karinių veiksmų moralumo klausimą, bet ir praktiškai issitikinti, kurie šios srities moralinès teologijos principai veikia realybeje ir kurie nesiekia toliau nei sofistiniai pasvarstymai. Perdèm nesileisdami $\mathfrak{i}$ gilius istorinius svarstymus, atkreipsime dèmesị tik ị vieną iš daugelio Romos Katalikų Bažnyčios požiūrio ị karybą formavimosi elementų, t. y. ̨̣ tai, kaip karo teisès pradininku paprastai laikomas dominikonas Fracisco de Vitoria ( 1483-1546 m.) savo veikaluose, remdamasis Naujojo pasaulio užkariautojų elgesiu su vietos indènais, iš teologinès perspektyvos svarstė užkariautojų elgesio moralumą, valstybių tarpusavio santykius, aplinky-

1 Plg. Pronckus R. Pjūklo ketera (Hacksaw Ridge): Viena tikèjimo pusė [interaktyvus], 20161201 [žiūrèta 201809 30]. Prieiga per internetą: < https://www.zurnalaskinas.lt/ kino-teatras/2016-12-01/Pjuklo-ketera-Hacksaw-Ridg>.

2 Terminai „gynyba ginklu“ ar "ginkluota gynyba“ ir jų modifikacijos šiame tekste atspindi gynybinius interesus, kai naudojamas ginklas ir yra tikimybè, kad agresorius bus sustabdytas atimant jam gyvybę.

3 Beresnevičius G. Naujojo atgimimo išvakarès: kontrsekuliarizacijos kontūrai Lietuvai. Vilnius, 2005, p. 50. 
bes, kuriomis valstybė gali teisètai pradèti karą, ir pan. Jo kelti klausimai tapo dabartinès tarptautinès teisès teorijos pamatu ${ }^{4}$. Tuo norima pabrèžti, kad dabartinę humanitarinę teisę iš dalies formavo būtent $\mathrm{RKB}$, tad remtis jos mokymo dèmenimis ne tik įmanoma, bet ir pageidautina.

Aptariant šią temą svarbu suprasti, kad ištisus šimtmečius RKB ne tik save suvokẻ kaip carito darbų ir artimojo meilès skelbejją, bet ir, kaip bet kuri labiau išsivysčiusi religija, nuklysdavo ị uzurpacinio karo laukus, pateisindavo amoralų elgesị su savo priešais. Net ir nesigilinant $\mathfrak{i}$ istorines vingrybes bei to meto politiką ir dvasingumą, dera atkreipti démesị, jog Bažnyčia save visuomet suvokè kaip Ecclesia militans dèl to, C. S. Lewiso žodžiais tariant, kad „krikščionybė yra kovojanti religija“" Jos kovos laukas apėmè kovą už tiesą ir žemę, kovą su vergovine santvarka ir kovą su eretikais. Kovota įvairiais būdais. Po kryžiaus karų etapo, o ypač atsiradus Fracisco de Vitorios teologinei krypčiai, RKB suvokè, kad „labai didelé ekonominé, socialinè nelygybė tarp tautų kelia ịtampą ir nesantaiką bei grasina taikai"“6, tad karybos ir gynybos klausimai ne kartą buvo paliesti ir gvildenti Bažnyčios mokyme. Visos kovos, kad ir kokios būtų, leido plètoti įvairių sričių teologiją, taip pat ir moralinès teologijos požiūrị i karą ir būtinąją gintị bandant išsaugoti tautos laisvę, valstybès suverenumą ir jos piliečius.

Benediktas XVI pranešime pasaulinès taikos dienos proga $(2006 \mathrm{~m}$. sausio 1 d.) pažymejo, kad taika - ne „paprastas karo nebuvimas, bet atskirų piliečių sugyvenimas teisingumo valdomoje visuomeneje, kurioje kiek įmanoma igyvendinamas gèris ${ }^{{ }^{*}}$, todèl be galo svarbus santykio tarp valstybių apsibrěžimas ir bandymas išsaugoti tokį trapų taikos būvị. Popiežius Paulius VI pastebejjo, kad visuotinis solidarumas, kuris tikrai egzistuoja, mums ne tik teikia naudą, bet kartu yra ir pareiga ${ }^{8}$, tad ši solidarumą ir taiką dera puoselèti elgiantis pagal bendrą moralès suvokimą, taip pat remiantis prigimtine teologija. Bendra morale ir žmogaus pri-

4 Plg. Woods T. E. Kaip Katalikų Bažnyčia sukūrė Vakaru civilizaciją. Vilnius, 2016, p. $145-146$.

5 Lewis C. S. Tiesiog krikščionybè. Vilnius, 2007, p. 57.

6 Popiežius Paulius VI. Enciklika POPULORUM PROGRESSIO apie tautu vystymąsi. Vilnius, 2010, $₫ 76$.

7 Benediktas XVI. Dvasines mintys. Vilnius, 2006, p. 72.

8 Plg. Popiežius Paulius VI. Enciklika POPULORUM PROGRESSIO apie tautų vystymasi. Vilnius, 2010, § 17. 
gimtinès teisès čia atpažįstamos ir apibréžiamos labiau antropologiniu ir bendražmogiškuoju kontekstu ir sugyvenimu, nes jokia „valstybè nèra moraliai autonomiška"9 ir visi mes gyvename pagal tą pačią prigimtinę teologiją. Galų gale ir valstybes saisto ta pati tarptautinè teisé, kuria vadovaujamasi ne tik taikos metu, bet ir esant karo padéčiai, o tai suponuoja prielaidą, kad, siekdami bendro gèrio, esame vieni nuo kitų priklausomi. Čia kalbama ne tik apie pavienius individus, bet ir apie tautas, valstybes.

Katalikų Bažnyčios katekizmas (toliau - KBK) skelbia, kad „pagarba žmogaus gyvenimui ir jo plètojimuisi reikalauja taikos. Taika nèra vien karo nebuvimas; jos negarantuoja ir priešiškų jègų pusiausvyra" (KBK $2304)^{10}$, tad RKB, matydama trapią politinių jègu pusiausvyrą, suvokia, kad karas gali kilti bet kurią akimirką ir bet kurioje vietoje. Iš čia išplaukia suvokimas, kad taika yra „visada trapus jègų pusiausvyros vaisius" ${ }^{\text {"11 }}$ ir tai, kad agresoriui užpuolus valstybę kyla gynybos būtinybė, tad moralinès teologijos principai skatina gilinti ši suvokimą, idant krikščionys ramia sąžine galètų ginti savo kraštą nuo neteisèto užpuolimo, okupacijos ir kitokių karinio pobūdžio agresoriaus veiksmų. Žinoma, net ir priešiškai valstybei pradejjus karinius veiksmus, Bažnyčia ragina besiginančią tautą neskubèti iškart naudoti ginkluotos gynybos, nes egzistuoja kolektyvinè atsakomybè, įsipareigojimas stabdyti karą. Karas - kraštutinė priemonè ir, jei jo įmanoma išvengti taikiu susitarimu, geriau daryti viską, kas įmanoma, kad nekiltų ginkluotas konfliktas.

Atkreiptinas dèmesys, jog RKB pritaria minčiai, kad valstybè turi turèti savo kariuomenę. Apie tai interviu, duotame žurnalistams grị̌ztant po vizito Lietuvoje, kalbejo ir popiežius Pranciškus. Jis minejjo, kad, „norint apsaugoti šalị, reikia turèti pamatuotą, bet ne agresyvią karinę struktūrą" ${ }^{\text {"12 }}$. Nors karinès galios didinimas ir nepanaikina karinių konfliktų kilimo pavojaus, RKB Magisteriume teigiamai kalba apie galimybę

\footnotetext{
9 Woods T. E. Kaip Katalikų Bažnyčia sukūrẻ Vakarų civilizacija. Vilnius, 2016, p. 156.

10 Čia ir kitur cituojamas Katalikų Bažnyčios katekizmas. Vilnius, 2015. Nuorodos žymimos santrumpa KBK ir paragrafo numeriu.

${ }^{11}$ Popiežius Paulius VI. Enciklika POPULORUM PROGRESSIO apie tautu vystymąsi. Vilnius, 2010, $₫ 76$.

12 Žiugždaitė S. Popiežius žurnalistams lèktuve: Stipriai išgyvenu Baltijos šalių istoriją [interaktyvus], 20180926 [žiūrèta 201809 28]. Prieiga per internetą: <http://www.bernardinai.lt/straipsnis/2018-09-26-popiezius-zurnalistams-lektuve-stipriai-isgyvenau-baltijos-saliu-istorija/172034>.
} 
šaliai turèti savo kariuomenę ir apskritai apie karo tarnybą, kurią regi ne tik kaip teisę, bet ir kaip prievolę.

Teiginys, trumpai apibrèžiantis RKB požiūrị i karo tarnybą, skambètų taip: „Kas yra pasiryžęs tarnauti tėvynei kaip karys, tas yra tautų saugumo ir laisvès gynejas. Deramai atlikdamas savo pareigas, jis tikrai prisideda prie tautos bendrojo gèrio ir taikos išsaugojimo“ (KBK 2310); asmuo, vengiantis karo tarnybos, kai ji privaloma, dẻl sąžinès ar įsitikinimų, turi būti pasirengęs atlikti alternatyviąją tarnybą; kiekvienas asmuo, tarnaujantis ginkluotosiose pajègose, yra pašauktas ginti gèrị, tiesą ir teisingumą ${ }^{13}$. O pratęsiant popiežiaus Pranciškaus mintị, galima drąsiai teigti, kad „yra pagrịsta teisè turèti karinę struktūrą, siekiant apsiginti, nes tai tiek pat teisèta, kiek turèti raktą nuo savo namu“"14.

Karai yra neišvengiamybè, todèl svarbu turèti galimybę apsiginti. Tas, kuris atlieka karo ar alternatyviąją tarnybą, nenusižengia moralès įstatymams, tačiau tas, kuris vengia karo arba alternatyviosios tarnybos, kuri padeda išlaikyti taiką arba ginti savo kraštą, nusižengia moralei, vadinasi, nusideda.

\section{GYNYBOS GINKLU MORALUMAS}

Kalbėdami apie tikejjimą ir karą, neišvengsime temos, kiek krikščionis privalo būti pacifistas, ypač jei diskusija vyksta viešajame diskurse arba tarp krikščioniškųjų denominacijų. Šis įsitikinimas gajus, ypač tarp protestantiškųjų ir naujųjų krikščioniškųjų religinių judejjimų, tad iškart dera pažymėti, kad čia kalbėsime tik apie RKB poziciją, kuri gali kardinaliai nesutapti su kitų denominacijų ir konfesijų (pvz., Septintosios dienos adventistų bažnyčios), taip pat kvazikrikščioniškųjų bendruomenių (pvz., Jehovos liudytojų) požiūriu.

Iškart pažymėtina, kad RKB, nors ir kovoja už taiką pasaulyje, nesilaiko šios radikaliojo pacifizmo pozicijos. Tai svarbu, nes pacifizmas, nors

13 Plg. Компендиум социального учения Церкви. Москва, 2006, § 502-503.

14 Žiugždaitė S. Popiežius žurnalistams lèktuve: Stipriai išgyvenu Baltijos šalių istoriją [interaktyvus], 20180926 [žiūrèta 201809 28]. Prieiga per internetą: <http://www.bernardinai.lt/straipsnis/2018-09-26-popiezius-zurnalistams-lektuve-stipriai-isgyvenau-baltijos-saliu-istorija/172034>. 
ir propaguoja nekovini pasipriešinimą, nesuderinamas su RKB savivoka. Pacifizmas suponuoja pasyvų leidimą agresoriui daryti žalą, o, kaip jau buvo pasakyta anksčiau, RKB samprata atitinka Ecclesia militans nuostatas, kad „negalima nei žmogui, nei valstybei, nei visuomenei atimti pagrindinès teisès ị savigyną ir í gynybą ginklu"15. Ši teisė suvokiama kaip pamatinè ir kylanti iš žmogaus, kaip Dievo paveikslo ir kūrinio, sampratos, todèl tikintysis privalo aktyviai priešintis karo keliamam blogiui.

Dèl valstybès gynimo RKB laikosi požiūrio, kad tai yra bendrojo gèrio gynimas, o „bendrasis gèris apima taiką, tai yra teisingos taikos tvarumą ir saugumą. „Bendruoju gèriu grindžiama asmens ir kolektyvo savigynos teisè“ (KBK 1909). Vadovaujantis šia samprata, gynyba karo atveju bendrąa prasme suvedama ị du esminius aspektus: a) valstybės gynimą ir b) valstybès piliečių gynimą. Šie du aspektai tarpusavyje glaudžiai ir esmiškai susiję, tad ir gynybos klausimu apibrèžiami remiantis tais pačiais principais - būtinosios ginties teise ir prigimtine teise ị savo gyvybès išsaugojimą.

RKB moralinèje teisèje numatyti keli atvejai, kai pateisinamas kito žmogaus nužudymas. Vienas iš šių atvejų ir yra būtinoji gintis. Pažymima, kad tas, „kas veiksmu kèsinasi ị kitų žmonių gyvybes, turi būti sustabdytas, net jei pats užpuolikas būtų nužudytas" ${ }^{16}$. Šis atvejis remiasi būtinosios ginties teise ir žmogaus gyvybès neliečiamumu. Žmogaus gyvybès neliečiamumas suponuoja bet kokị draudimą žudyti, tačiau KBK pabrěžiama, kad, „kas gina savo gyvybę, nenusikalsta žmogžudyste, net jeigu yra priverstas suduoti mirtiną smūgị užpuolikui $<\ldots>$ būtinoji gintis gali būti ne tik teisè, bet ir svarbi pareiga tam, kas yra atsakingas už kito gyvybę“" (KBK 2264-2265). Tad gindamas ir savo, ir kito asmens gyvybę asmuo nenusikalsta, net jei agresorius yra nužudomas. Tokiu gyvybès atèmimo atveju nužudymas nelaikomas gèriu, bet nelaikomas ir nuodème. Tad tokị agresoriaus gyvybės atėmimą derètų vertinti kaip (ne)išvengiamą būtinybę. Žinoma, čia dera nepamiršti, kad „tyčinis nekalto žmogaus nužudymas yra sunkus nusikaltimas“ (KBK 2261), todèl bet kokia gynyba, net ir ginkluota, neturi peržengti būtinosios ginties ribų. Taip pat dera suprasti, kad „būtinoji žmogaus ir visuomenès gintis nèra draudimo žudyti nekaltą žmogų, tyčinès žmogžudystès išimtis“ (KBK 2263), tai la-

\footnotetext{
15 Youcat: Jaunimo katekizmas. Vilnius, 2011, § 398.

16 Ten pat, $₫ 380$.
} 
biau bendrojo gèrio, kuris reikalauja neteisètą užpuoliką padaryti nepavojingą, gynimas.

Išeities tašku laikyti anksčiau išsakyti RKB mokymo dėmenys implikuoja tautos gynimąsi ginklu kaip morališkai leistiną, tačiau nepažeidžiant protingumo ir proporcingumo kriterijų. Negana to, karo ar kitu atveju, kai kyla pavojus nekaltų žmonių gyvybei, „teisèta valdžia turi teisę net ginklu atremti gyventojų, už kuriuos ji atsakinga, užpuolikus“" (KBK 2265). Čia taip pat svarbu ir tai, kad nors karas ir yra suvokiamas kaip moraliai blogas vyksmas, tačiau, jam kilus, valstybių vadovai turi teisę, pareigą ir net prievolę organizuoti gynybą, taip pat ir ginkluotą ${ }^{17}$. Visa būtinoji gintis ir ginkluotas gynimasis karo atveju remiasi postulatu, kad „žmogaus gyvybė yra dovana, gintina nuo ịvairialypio naikinimo “18, todèl „žmogus negali žudyti kito žmogaus, išskyrus būtinos ginties atveju ar gelbèdamas(is) iš kraštutinès bèdos" ${ }^{\text {"19 }}$.

Šventasis Tomas Akvinietis pažymëjo, kad savigyna (šiuo atveju ir tèvynès gynimas ginklu) turi du galimus padarinius: savosios gyvybès išsaugojimą ir užpuoliko mirtị. Abu šie padariniai yra įmanomi, tik iš jų pirmasis yra norimas, o antrasis - ne (plg. KBK 2263). Todèl besiginantys asmenys ar tautos turi teisę panaudoti jègą gindami tuos, kurie patys negali apsiginti nuo agresoriaus ${ }^{20}$, nes ir vienu, ir kitu atveju būtinoji gintis yra ne tik teise, bet ir pareiga to, kuris atsakingas už kitų žmonių gyvybes $^{21}$.

Mūsų temos kontekste tai būtų tèvynès ir jos piliečių ginkluoto pasipriešinimo dalyviai, gynejjai ar šalies karinès pajègos. Popiežius Pranciškus šị teigini papildo teigdamas, kad „gynyba yra teisé, bet yra ir garbe் ${ }^{\text {“22 }}$. Taigi, galime teigti, kad asmuo, ginantis savo kraštą, elgiasi ne tik teisètai, bet ir garbingai, nors čia, žinoma, dera pažymèti, kad ginkluotų konf-

17 Plg. Компендиум социального учения Церкви. Москва, 2006, \$500.

18 Šventas Tëvas Pranciškus. Enciklika LAUDATO SI‘ apie rūpinimąsi bendrais namais. Kaunas, 2015, $\$ 5$.

19 Youcat: Jaunimo katekizmas. Vilnius, 2011, $\$ 378$.

20 Plg. Компендиум социального учения Церкви. Москва, 2006, \$504.

21 Youcat: Jaunimo katekizmas. Vilnius, 2011, $\$ 380$.

22 Žiugždaite S. Popiežius žurnalistams lekktuve: Stipriai išgyvenu Baltijos šalių istoriją [interaktyvus], 20180926 [žiūrèta 201809 28]. Prieiga per internetą: <http://www. bernardinai.lt/straipsnis/2018-09-26-popiezius-zurnalistams-lektuve-stipriai-isgyvenaubaltijos-saliu-istorija/172034>. 
liktų metu taip pat galioja moralinis įstatymas, o veiksmai, sąmoningai prieštaraujantys tarptautinei teisei ir jos principams, yra nusikalstami (plg. KBK 2328) ir moraliai nepateisinami. Galima teigti, kad asmenys, krašto gynimo metu besivadovaujantys karo ir humanitarinès teisès normomis, elgiasi moraliai teisingai, nes ši teisè nesikerta su tuo, ko apie krašto gynybą ginklu moko RKB moralinè teisè.

Būtinoji gintis pateisina valstybių ginkluotąsias pajègas, skirtas saugumui ir šalies laisvei bei taikai pasaulyje užtikrinti, todẻl kariai, paminantys žmogaus teises, elgiasi amoraliai, o jų veiksmai yra moraliai nepateisina$\mathrm{mi}$, net jei jie pakluso teisètam įsakymui ${ }^{23}$, nes „tarptautinei teisei ir visuotiniams jos principams sąmoningai priešingi veiksmai, kaip ir įsakymai juos vykdyti, yra nusikaltimai“ (KBK 2313). Ginkluotųų pajėgų karys turi moralinę teisę priešintis ịsakymams, kurie reikalauja įvykdyti nusikaltimą žmogaus teisėms, nes, „karui jau kilus, tai dar nereiškia, kad kovojant su priešu visa yra leistina“24. RKB pabrèžia, kad „doroviniu požiūriu karas leistinas tik kaip paskutinė priemone் “25, o popiežius Pranciškus pažymi, kad „problema kyla, kai gynyba tampa agresyvi ir nepagrịsta“26.

Žinoma, pagal RKB, esama asmenų, kurie dèl sąžinès ar įsitikinimų nenori imti ginklo ị rankas, todèl Magisteriumas atkreipia dėmesị $\mathfrak{i}$ tai, jog „teisinga, kad įstatymai žmogiškai atsižvelgtų i tuos, kurie remdamiesi sąžinès motyvais atsisako vartoti ginklus, jei tik yra pasiruošę kitokiu būdu tarnauti žmonių bendruomenei“"27. Čia mes galime izžvelgti du svarbius mūsų tema dalykus: a) kiekvienas asmuo privalo prisidèti prie tèvynès bendrojo gèrio ją gindamas ir b) ginklu ar be jo kiekvienas valstybès pilietis privalo ginti tèvynę.

23 Plg. Компендиум социального учения Церкви. Москва, 2006, § 502-503.

24 Pastoracinė konstitucija apie Bažnyčią šiuolaikiniame pasaulyje GAUDIUM ET SPES // II Vatikano nutarimai. Vilnius, 2001, \$79.

25 Youcat: Jaunimo katekizmas. Vilnius, 2011, \$398.

26 Žiugždaitė S. Popiežius žurnalistams lèktuve: Stipriai išgyvenu Baltijos šalių istoriją [interaktyvus], 20180926 [žiūrèta 201809 28]. Prieiga per internetą: <http://www.bernardinai.lt/straipsnis/2018-09-26-popiezius-zurnalistams-lektuve-stipriai-isgyvenau-baltijos-saliu-istorija/172034>.

27 Pastoracinė konstitucija apie Bažnyčią šiuolaikiniame pasaulyje GAUDIUM ET SPES // II Vatikano nutarimai. Vilnius, 2001, \$79. 
Kol kas „karas tikrai nèra pašalintas iš žmonių tarpo. O kol tebèra karo pavojus ir nèra kompetentingos tarptautinès valdžios, turinčios atitinkamas pajėgas, tol valstybèms negalima paneigti teisès leistinu būdu gintis, prieš tai išbandžius visus taikaus susitarimo būdus“28, todèl ginkluotas pasipriešinimas vertinamas kaip galima, bet kraštutinè priemonè. Ši priemonẻ laikoma moraliai pateisinama, jei taikūs būdai išvengti ginkluoto karinio konflikto yra beprasmiai arba jau išbandyti.

Jejgos ir ginklo naudojimas gynybai laikomas moraliai pateisinamu, jei atitinka šiuos reikalavimus: agresoriaus veiksmai ir žala tautai yra ilgalaikiai, sunkūs ir neginčijami; jei jokiomis kitomis priemonėmis agresoriaus neįmanoma sustabdyti; jei ginklo naudojimas neprives prie dar didesnio blogio nei blogis, kurị norima sustabdyti, čia ypač dera atsižvelgti i masinio naikinimo ginklų panaudojimo galią ${ }^{29}$.

Savaime suprantama, kad „reakcija i smurtą tarptautiniu lygiu priklauso nuo valstybès ar vyriausybès karinio ir ekonominio pajėgumo. Jei valstybė gali sau leisti, ji už patirtą smurtą griebiasi atsilyginti kerštu. Priimant tokius sprendimus ne itin atsižvelgiama $\mathfrak{i}$ faktą, kad dèl to labiausiai nukenčia nekalti civiliai žmonès “30, todèl valstybė turètų rūpintis gynyba, o ne kerštu ar puolimu, nes tik gynybos atveju ginklo naudojimas būtų moraliai pateisinamas. Negana to, „valstybès valdžiai tada tenka teisè ir pareiga ịpareigoti piliečius atlikti kas būtina valstybei apginti“ (KBK 2310).

Atkreiptinas dèmesys ị tai, kad „viena yra vartoti ginklus teisètai tautos gynybai, o kita - siekiant pavergti kitas tautas“" ${ }^{31}$. Pirmuoju atveju ginklo naudojimas leistinas ir moraliai pateisinamas, antruoju - laikomas baisiu nusikaltimu. Akivaizdu, kad tarptautinius santykius reguliuoti ir gintis, esant galimybei, derètų be ginklo, tačiau, kai būtina, ginklo naudojimas ginantis ar ginant savo kraštą yra moraliai pateisinamas, nes kiekvieno žmogaus ir valstybės piliečio teisė gyventi susijusi su prievole ir galimybe saugoti savo ir artimųjų gyvybę. Teise priešintis, net ir ginklu, remiasi prigimtine teise ị savo gyvybès ir nacijos suverenumą ir išsaugojimą.

\footnotetext{
28 Ten pat.

29 Plg. Компендиум социального учения Церкви. Москва, 2006, $\$ 500$.

30 Düring J. Su smurtu susidūrus. Krikščioniškieji savigynos principai. Vilnius, 2012, p. 17.

31 Pastoracinė konstitucija apie Bažnyčią šiuolaikiniame pasaulyje GAUDIUM ET SPES // II Vatikano nutarimai. Vilnius, 2001, \$79.
} 
Taip pat dera atkreipti demesị ir $\mathfrak{i}$ tai, kad RKB smerkia masinio naikinimo ginklų naudojimą. Magisteriume pabrèžiama, kad „kiekvienas karo veiksmas, nešantis beatodairišką naikinimą ištisiems miestams arba plačioms sritims drauge su jų gyventojais, yra nusikaltimas Dievui bei pačiam žmogui ir turi būti griežtai ir nedvejojant pasmerktas ${ }^{\text {"32 }}$. Karine galia nedaro jos naudojimo teisètu, siekiant karinių ar politinių tikslų, tačiau, jei karas prasidèjo, dera žinoti, kad kariaujančioms pusèms ne viskas leidžiama. Anot Jono Pauliaus II, teisès gynybai igyvendinimas neturi peržengti „tradicinių būtinumo ir proporcingumo rèmų“33, nes, popiežiaus Pauliaus VI žodžiais tariant, „su tikru blogiu negalima kovoti taip, kad rastųsi dar didesnè blogybé ${ }^{\text {“34 }}$.

\section{KITO SKRUOSTO ATSUKIMO KLAUSIMU}

Religijotyrininkè Karen Armstrong pastebi, kad „Biblijoje tikrai yra nemažai smurto - daug daugiau negu Korane ${ }^{{ }_{35}}$, tad natūralu, jog bibliniame kontekste smurto, karo ir gynybos klausimai buvo paliesti arba svarstyti, nes puikiai suvokiamas karo pavojaus realumas ir tai, kad norintis išlikti tikintysis negali likti pasyvus stebėtojas ir laukti, kol angelai ar pats Dievas išgelbės tautą. Koheleto knygoje rašoma: „Viskam yra metas, ir kiekvienam reikalui tinkamas metas po dangumi <...> Laikas žudyti ir laikas gydyti, laikas griauti ir laikas statyti <...> Laikas myleti ir laikas nekęsti, laikas karui ir laikas taikai.“ (Koh 3, 1.3.8) ${ }^{36}$ Nors ir „Naujajame Testamente neabejotinai esama kovos metaforų, pavyzdžiui, kalbant apie tikejjimo tvirtumą “" ${ }^{37}$, o Biblijoje „kariuomenès prasmè daugiausia pateikiama kaip Dievo valios sąlyga, karys siejamas su dieviškojo kario, kurio

\footnotetext{
32 Ten pat, $\$ 80$.

33 Plg. Компендиум социального учения Церкви. Москва, 2006, §. 501.

34 Popiežius Paulius VI. Enciklika POPULORUM PROGRESSIO apie tautų vystymąsi. Vilnius, 2010, $\$ 31$.

35 Armstrong K. Biblija: Knygos biografija. Vilnius, 2008, p. 227.

36 Šventojo Rašto tekstai cituojami iš: Biblija, arba Šventasis Raštas. Ekumeninis leidimas. Vilnius, 2017, nebent nurodyta kitaip.

37 Ansorge D. Smurtas krikščionybės vardu? // Bažnyčios žinios (Katalikų Bažnyčios Lietuvoje informacinis biuletenis Nr. 3(441)). Kaunas, 2017, p. 30.
} 
tikslas - saugoti žmones, įvaizdžiu“"38. Tačiau čia aptarsime tik vieną populiariausią jos teiginị - apie skruosto atsukimą skriaudikui.

Norėdami išsakyti poziciją agresoriaus atžvilgiu, krikščionys paprastai cituoja Evangelijoje pagal Matą pasakytus Jėzaus žodžius: „Nesipriešink piktam [žmogui], bet jei kas tave užgautų per dešinị skruostą, atsuk jam ir kitą." (Mt 5, 39)

Ši citata paprastai pateikiama kaip klasikinis pavyzdys, nurodantis, kad krikščionis privalo leistis žeminamas, mušamas ir visaip niekinamas. Čia „kito skruosto atsukimas, ịpareigojimas mylèti priešą ar būti pasiruošus visada visiems atleisti. Laikydamasis tokio požiūrio, kiekvienas geras krikščionis turètų būti auka, žmogus, kuris ne tik leidžiasi be saiko žeminamas, bet dar ir nepyksta ant savo kankintojų “39. Tačiau toks kraštutinis požiūris neatitinka krikščioniškosios pasaulèžiūros ir biblinio požiūrio, juo labiau kad šią šventraščio citatą galima interpretuoti ịvairiai. Vieną iš galimų interpretacijų dabar trumpai ir apžvelgsime.

Evangelijos pagal Matą kito skruosto atsukimo problematika paprastai traktuojama kaip ìsakymas leistis būti mušamam, niekinamam ir kankinamam. Paprastai, vadovaujantis čia citata, bandoma pateisinti kentèjimą dèl Kristaus ir taip jungtis prie jo kančios ant kryžiaus. Interpretacijos galimos ịvairios, tačiau, bandant suvokti visuminị aptariamos straipsnio temos kontekstą, gali padeti pažodinis teksto vertimas, nušviečiantis kiek kitokị požiūrị, nei ịprasta. Čia mums pagelbès Naujojo ekumeninio Mato evangelijos vertimo tekstas ir jo komentaras.

Išverstas pažodžiui tekstas skambètų taip: „Nesipriešink piktai, bet jei kas tau trenktų per dešinị skruostą, atsuk jam kitą. " Komentare rašoma, jog vertimas mums kalba apie stovèjimą priešpriešiais, tačiau be pykčio, t. y. nepiktą. Tekste nekalbama apie visišką nesipriešinimą, tik kalbama apie nesipriešinimą pykčiu. Vien jau kito skruosto atsukimas suponuoja priešpriešą. Veiksmažodis antihistēmi, kuris čia ir vartojamas kalbant apie nesipriešinimą, turi karinị reikšminị atspalvị, reiškiantị kariuomenès išrikiavimą mūšiui ${ }^{40}$.

38 Bielinytė I. Karybos elementai Biblijoje. Kariūnas, 2015, Nr. 1 (124), p. 39.

39 Düring J. Su smurtu susidūrus. Krikščioniškieji savigynos principai. Vilnius, 2012, p. 10.

40 Plg. Evangelija pagal Matą. Naujas ekumeninis vertimas. Vilnius, 2017, p. 35-36. 
Pažodinis teksto vertimas atskleidžia kitokią priešinimosi dimensiją. Šis tekstas - apie aktyvius veiksmus, o ne apie pasyvų kentėjimą. Kariuomenès išrikiavimo mūšiui momentas suponuoja tolesnị veiksmą - gynimąsi, kuris retai būna be aukų. Vadovautis šia interpretacija galima ir diskutuojant Tẻvynès gynimo ginklu klausimu. Kaip ir šioje ištraukos interpretacijoje, gintis karo atveju ne tik leistina, bet ir privaloma.

Gana išsamiai šios interpretacijos aspektus yra nagrinëjęs vienuolis benediktinas, aikido meistras Jonathanas Düringas. Jo samprotavimai paremti ne tik giliomis teologinėmis, bet ir kovos meno teoretikų ižvalgomis. Brolis Düringas čia kelia klausimą: kodèl Jèzus kalba būtent apie dešinị skruostą? Jei norima kitą sužeisti, iš pradžių smogiama dešinès rankos kumščiu, o toks smūgis pirmiausia taikomas ị kairị skruostą. Tačiau ne bandydamas fiziškai smurtauti, o norèdamas paniekinti ar pažeminti, skriaudikas smogtų dešinès rankos išorine puse. Tad Jèzus kalba ne apie pasyvumą fizinio smurto atveju, o apie poziciją, kai asmuo yra žeminamas. Kito skruosto atsukimas taip pat yra ir iššūkio metimas skriaudikui, nes taip parodoma, kad priešininko nebijoma ir skriaudžiamasis yra ne žemesnio, bet lygaus statuso asmenybè, tad čia pereinama ị aktyvaus pasipriešinimo poziciją ${ }^{41}$. Taip pat vertètų prisiminti kunigo jėzuito Jono Juraičio mintis, papildančias šias įžvalgas: „Jèzus neliepia atsukti vaiko, tautos, beginklio skruosto žudikui. Smurtautojui leista atsukti tik savo skruostą <...> apeliuojant ị šiuos žodžius apie antausị, krikščionio pasirengimas iškęsti neteisybę painiojamas su pasirengimu neveikliai stebėti, kaip neteisybė daroma kitam" ${ }^{\text {“42 }}$.

Taigi biblinè gynimosi samprata gali būti išsakyta šiais katekizmo žodžiais: „Evangelijos dvasia nesuderinama su neapykanta priešui, kaip asmeniu, bet ne su neapykanta priešo daromam blogiui“ (KBK 1933), todèl bet kokie blogi darbai turi būti stabdomi.

41 Plg. Düring J. Su smurtu susidūrus. Krikščioniškieji savigynos principai. Vilnius, 2012, p. $94-95$.

42 Juraitis J. Išmelsta ir išdrebèta išmintis. Kaunas, 2017, p. 48. 


\section{IŠVADOS}

Apžvelgę Romos Katalikų Bažnyčios dokumentus ir kai kurių teologų mintis aptariamaja tema, priejome prie šių išvadų:

1. Agresoriui užpuolus valstybę, jos piliečiai turi teisę ir prievolę ginti savo šalị.

2. Ginklą naudoti gynybai leistina, jei visos kitos priemonès nenaudingos arba beprasmès.

3. Ginantis ginklu privaloma laikytis būtinosios ginties sąlygų, o ginant savo valstybę - tarptautinės teisės principų, karo įstatymų ir papročių. Priešingu atveju veiksmai bus neteisèti ir moraliai nepateisinami.

4. Bet koks žudymas - nuodemingas veiksmas, tačiau būtinosios ginties atveju daroma išimtis ir agresoriaus nužudymas, jei kitaip neįmanoma jo sustabdyti, moraliai pateisinamas, todèl gali būti nelaikomas nuodèmingu veiksmu.

5. Gindami savo kraštą ginklu ar kitais būdais, piliečiai naudojasi prigimtine teise ginti savo gyvybę ir tautos suverenumą. Tas, kas ginklu ar be jo gina savo šali, elgiasi garbingai.

6. Moraliai nepateisinamas masinio naikinimo ginklo naudojimas. Proporcingumo ir protingumo principo nesilaikymas ginantis taip pat laikomas amoraliu.

7. Bibliniame kontekste, apsvarsčius vieną iš dažniausiai netikslų požiūrị i gynybą formuojančių Naujojo Testamento citatų, būtent Mt 5 , 39, prieita prie išvados, kad krikščionis, noredamas laikytis Evangelijos nuostatų, privalo gintis ir ginti savo artimą.

\section{ŠALTINIAI}

1. Ansorge, D. Smurtas krikščionybės vardu? // Bažnyčios žinios (Katalikų Bažnyčios Lietuvoje informacinis biuletenis Nr. 3(441)), Kaunas, 2017.

2. Armstrong, K. Biblija: Knygos biografija. Vilnius, 2008.

3. Benediktas XVI. Dvasines mintys. Vilnius, 2006.

4. Beresnevičius, G. Naujojo atgimimo išvakarès: kontrsekuliarizacijos kontūrai Lietuvai. Vilnius, 2005. 
5. Biblija, arba Šventasis Raštas. Ekumeninis leidimas. Vilnius, 2017. (124).

6. Bielinyte, I. Karybos elementai Biblijoje. Kariūnas, 2015, Nr. 1

7. Düring, J. Su smurtu susidūrus. Krikščioniškieji savigynos principai. Vilnius, 2012.

8. Evangelija pagal Mata. Naujas ekumeninis vertimas. Vilnius, 2017.

9. Youcat: Jaunimo katekizmas. Vilnius, 2011.

10. Juraitis, J. Išmelsta ir išdrebèta išmintis. Kaunas, 2017.

11. Kataliku Bažnyčios katekizmas. Vilnius, 2015.

12. Компендиум социального учения Церкви. Москва, 2006.

13. Lewis, C. S. Tiesiog krikščionybè. Vilnius, 2007.

14. Pastoracinè konstitucija apie Bažnyčią šiuolaikiniame pasaulyje GAUDIUM ET SPES // II Vatikano nutarimai. Vilnius, 2001.

15. Popiežius Paulius VI. Enciklika POPULORUM PROGRESSIO apie tautu vystymąsi. Vilnius, 2010.

16. Pronckus, R. Pjūklo ketera (Hacksaw Ridge): Viena tikejimo pusè [interaktyvus], 20161201 [žiūrèta 201809 30]. Prieiga per internetą: $<$ https://www.zurnalaskinas.lt/kino-teatras/2016-12-01/Pjuklo-keteraHacksaw-Ridg>.

17. Šventas Tẻvas Pranciškus. Enciklika LAUDATO SI'apie rūpinimasi bendrais namais. Kaunas, 2015.

18. Woods, T. E. Kaip Kataliku Bažnyčia sukūré Vakaru civilizaciją. Vilnius, 2016.

19. Žiugždaitè, S. Popiežius žurnalistams lèktuve: Stipriai išgyvenu Baltijos šalių istoriją [interaktyvus], 20180926 [žiūrèta 201809 28]. Prieiga per internetą: $<\mathrm{http}$ ///www.bernardinai.lt/straipsnis/2018-09-26-popiezius-zurnalistams-lektuve-stipriai-isgyvenau-baltijos-saliu-istorija/172034>.

Itteikta $2018 \mathrm{~m}$. spalio $16 \mathrm{~d}$. 


\section{DEFENCE OF HOMELAND USING WEAPONS: SIN OR VIRTUE? THE APPROACH OF THE CATHOLIC CHURCH}

\section{Licentiate of Sacred Theology Gabrielius Edvinas KLIMENKA Vytautas Magnus University, Lithuanian Riflemen's Union}

The article reveals the attitude of the Roman Catholic Church towards the defence of homeland using weapons from the perspective of moral theology. It introduces the problem the essence of which is a wrong conviction among Catholics and others that the doctrine of the Roman Catholic Church prohibits to defend one's country using weapons.

Based on the documents of the Roman Catholic Church and the insights of the theologians, the article reveals the Magisterium's attitude to war and peace. The latter is presented as a fragile balance between international relations and power which at any time can lead to war. It is emphasized that peace is not an elementary lack of war. Peace is an effort of solidarity of all the countries of the world. The article presents how the Magisterium describes military service, an alternative service to those who cannot use weapons due to conscience or moral convictions and the approach of the Magisterium to the state military forces. In this case, the defence of homeland is perceived as the right and duty of citizens to act honorably, while the avoidance proves incorrect behavior.

Based on the fact that the Roman Catholic Church does not support radical pacifism, another part discusses the morality of armed resistance and presents the criteria allowing the use of a weapon for defence, for example, when all the measures are exhausted and there is no other way to resolve an international conflict peacefully. It also explains the cases when the assassination of an aggressor is morally acceptable and permissible. The natural right to defend one's relatives and own life and to preserve the sovereignty of the nation is emphasized as well. The article also addresses the violations of international and military law.

The part that incorporates the biblical approach is limited to discussing a specific quotation, namely do not remember evil, but if it does light 
up on the right cheek, give it another (Mt 5:39) that is usually used to indicate the position the Christians should take when facing an aggressor. The article points out why the traditional concept does not correspond to the biblical or ecclesiastic theological ideas.

The article came to the conclusions that if an aggressor attacks the state, its citizens must defend their land; the use of weapon is permissible if it does not go beyond the reasonable and proportionate conditions. 